\title{
Neuroprotection of Anakinra on peripheral nerve neurodegeneration in single and combination protocols with TTR siRNA in a transgenic mouse model for human V30M transthyretin
}

\author{
Maria João Saraiva*, Paula Gonçalves, Diana Martins, Nádia Pereira Gonçalves \\ From First European Congress on Hereditary ATTR amyloidosis \\ Paris, France. 2-3 November 2015
}

\section{Background}

We previously showed the properties of interleukin- $1 \beta$ antagonist Anakinra on unmyelinated nerve fibers protection in a transgenic mouse model for human V30M transthyretin. In these studies, Anakinra decreased, among other markers, nerve levels of IL- $1 \beta, \mathrm{NF}-\kappa \mathrm{B}$ and activated-caspase 3 , associated with a decrease in TTRnon fibrillar deposition.

In the present work, we compared the efficacy of other compounds under human therapeutical trials for Familial Amyloidotic Polyneuropathy (FAP) in the same animal model, having 5 months of age.

\section{Methods}

V30M transgenic mice were treated daily with subcutaneous injections of Anakinra at $25 \mathrm{mg} / \mathrm{kg}$ over 6 weeks. Age-matched controls were injected with phosphate buffer saline (PBS). TTR siRNA, at a concentration of $1 \mathrm{mg} / \mathrm{kg}$ was injected in the tail vein for 4 weeks. One intravenous injection was performed per week and animals were euthanized $48 \mathrm{~h}$ after the last injection. Untreated age-matched controls received vehicle intravenously. Anakinra plus TTR siRNA combination therapy was performed using the same therapeutical design. In addition, other V30M mice group was treated with Tafamidis meglumine with 3 subcutaneous injections weekly, over 6 weeks. Controls received meglumine alone. Finally, combination strategy with Doxycycline/ TUDCA was also achieved in V30M mice. Animals were treated with $8 \mathrm{mg} / \mathrm{kg}$ Doxycycline daily in the

Instituto de Inovação e Investigação em Saúde (I3S), Instituto de Biologia Molecular e Celular (IBMC), Universidade do Porto, Molecular Neurobiology Unit, 4150-180, Porto, Portugal 
doi:10.1186/1750-1172-10-S1-P13

Cite this article as: Saraiva et al: Neuroprotection of Anakinra on peripheral nerve neurodegeneration in single and combination protocols with TTR siRNA in a transgenic mouse model for human V30M transthyretin. Orphanet Journal of Rare Diseases 2015 10(Suppl 1):

Submit your next manuscript to BioMed Central and take full advantage of:

- Convenient online submission

- Thorough peer review

- No space constraints or color figure charges

- Immediate publication on acceptance

- Inclusion in PubMed, CAS, Scopus and Google Scholar

- Research which is freely available for redistribution 